\title{
酵素機能電極とそのバイオセンサー＼cjkstart池田篤治* への利用
}

酵素反応と電極をメディエータを介した電子伝達共役によって結びつけ，これを種々の生体物質の測定などに利 用する試みが注目されている. 酵素機能電極と呼ばれるこのデバイスから得られる電流は, 基質特異性など酵素 触媒反応に特有の性質を示す．こうした生体系と非生体系の機能共役は生体機能分子のデバイス化の有望な方法 の一つであり、分子レベルでの研究が始まりつつある.

\section{酵素機能電極とは}

バイオセンサーといえば，酵素電極または電極 型酵素センサーと呼ばれているものがよく知られ ている.たとえば，グルコースオキシダーゼ固定 化膜で酸素電極を覆えば，グルコースセンサーと なる、酵素反応でグルコースが酸化されるときに 酸素が消費されるので，固定化膜中の酸素濃度が 下がり酸素電極の出力電流が減少する.この減少 量からグルニースを定量できるわけである．この 酵素反応は熱変化を伴らので，酸素電極の代わり にサーミスタと組み合わせてセンサーとすること もできる(1)。この例からもわかるように，このタ イプの酵素電極では酵素反応と電極との結びつき がそれほど強くない，それに比べて，ここでとり 上げる酵素機能電極では, 固定化酵素の触媒反応 々電極反応が一体化しておうり，文字ど扣り酵素の 機能を備えた電極といらことがでさる(2,3).

酵素機能電極で快, 図 1-A，Bに示すように電 極を酵素反応の電子受容体もしくは供与体として 用いる。そうすると，酵素（E）の基質 $(\mathrm{S})$ を 電気化学的に生成物（P） に酸化も乙くは還元す ることができる。たと壳ば，グルコースオキシダ 一ゼ（GOD）を用いると，裸の電極では酸化する ことが非常に困難なグルニース（Glc）を GOD の助けによってスムースに電解酸化できる，この よらな酵素触媒による電解反応をバイオェレクト ロカタリシスと呼んでいる。しかしながら，この

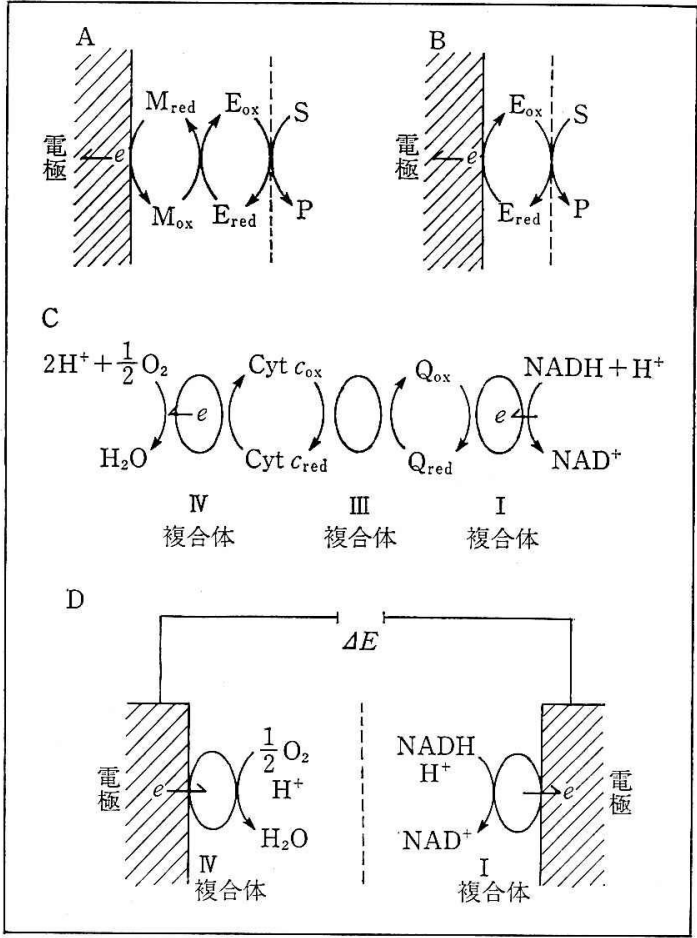

図 1】酵素機能電極とミトコンドリア電子伝達系 $\mathrm{A}$ ：メディエータを用いる醉素機能電極， B : 直接電子移動に 基づく酔素機能電極，C：ミトコンドリアの電子伝達系， D : 複合体 I, 複合体 $I V$ 学用い万生物電池

反応を実現するのはそれほど容易ではなく，電極 之酵素との電子の受け渡しを滑らかに行なわせる には特別の工夫がいる。たと壳ば，図 1-A の例 では，酵素の電子受容体として働く化合物を介し て電極に電子を渡している。このような化合物 として, ジクロロフェノールインドフェノール (DCIP) やへキサシアノ鉄 (III)酸イオンなどが知 られている.これらは多くの酸化還元䤏素の電子 
受容体として働き, 電極との反応も速やかに起こ る.すなわち，電子伝達メディエータ（M）とし て機能する.この方法に基づく酵素機能電極は 1980年代の初めころから研究が始まり, 現在バイ オセンサーとしての利用が大変注目されて拈り, すでに市販品も出始めている.

もう1つの方法は, 図 1-B に示すように酵素 と電極との直接電子移動を何とか実現しょうとす るものである、実際に，電極表面の生体分子適合 化, 酵素分子の改変などの試みが始まって和り, 生体系之非生体系とのインターフェインングの問 題の一つとして注目されている.ごく最近, いく つかの例が見られるようになった。

このようにして酵素-電極間の 電子移動が速や かに進行すれば, 様々の興味深い展開が期待でき る. バイオェレクトロカダリシスに和いては, 酵 素反応のターンオーバー数に相当する電子が単位 時間に電極に渡されるが，単位時間当たりの電子 の流れは電流に他ならないので, 電流を測定すれ ば酵素反応の速度が測定でき，したがって基質の 定量ができる、簡単な計算によると, GOD のよ うにその比活性が 100 ニニッ/mg（ターンオー バー数 (触媒定数) が約 $300 / \mathrm{s}$ ) 程度の酵素の場 合は, 酵素分子を単分子層 (約 $10^{-12} モ ル / \mathrm{cm}^{2}$ あるいは約 $200 \mathrm{ng} / \mathrm{cm}^{2}$ ) 程度に固定した電極で ๖ $100 \mu \mathrm{A}$ 程度の電流出力が期待できる. 今日の 電気化学計測に和いては $\mathrm{nA}$ 程度の電流測定でも 容易であるので, 分子のオーダーでデザインした 酵素機能電極をも十分研究対象とすることができ る.

酵素機能電極の生体酸化還元反応との対応をみ てみるのも興味深い. 図 1-C にミトコンドリア 膜に和汁る電子伝達系の模式図を示す.たとえ ば,この電子伝達系の任意の場所に電極を持って 来ることができれば，電子を引き抜いたり注入し たりできる. 複合体Iからの電子を電極に導けば $\mathrm{NADH}$ の電気化学的酸化ができるし, 電極から 複合体 $\mathbb{V}$ に電子を供給寸れば酸素の水への電解還 元が可能になる. また，これらの酸化還元タンパ ク質を固定化した $2 つ の$ 電極を図 1-D のように 組み合わせると, 外部に電気を取り出すことが原
理的に可能となる.すなわち, 次の反応,

$$
\mathrm{NADH}+1 / 2 \mathrm{O}_{2}+\mathrm{H}^{+} \longrightarrow \mathrm{NAD}^{+}+\mathrm{H}_{2} \mathrm{O}
$$

の自由エネルギー変化 $\left(\Delta G^{\prime}=-220 \mathrm{~kJ} / \mathrm{mol}\right.$, $\Delta E^{\prime}=1.14 \mathrm{~V}$ ) に近い電圧の 電池が期待できる. ミトコンドリア膜に和汀る酸化的燐酸化反応に対 応した生体反応電池と言兄る。委た，TCA サイ クルなど有機物からの $\mathrm{NADH}$ 再生系と共役させ れば，生物燃料電池となる。

以上, 一例を述べたように, 酵素機能電極は生 体分子の高次の機能を電極系に結び付けるもので あり, 酵素以外の生体機能分子や分子集合体, さ らにはオルガネラや細胞そのものをも対象として 含めることができる.この意味で, 酵素機能電極 はより一般化して生体触媒機能電極 (バイオカタ リスト電極）とも呼ぶことがでさる、ここでは焦 点をしぼって, バイオセンサーへの利用という観 点から, 酵素機能電極に関する研究の現状と今後 の問題について述べる.

\section{メディエータを用いる電気化学バイオセンサー}

\section{1. 酵素機能電極の構造と応答特性 ${ }^{(4,5)}$}

GOD を固定化した電極を例にとって，基本的 な応答特性を説明しょう，GOD は炭素電極の表 面に吸着固定することができる。この GOD 吸着 電極を少量のメディエータ會む Glc 溶液中に 入れて適当な電圧を加えると, Glc 濃度に依存し な酸化電流が得られる.メディエータとしては p-ベンゾキノン (BQ) のようなキノン類やフェ ロセン誘導体がよく用いられる，このとき図 1-A の反応は次のように書くことができる.

$$
\begin{aligned}
\mathrm{S}+\left(\mathrm{E}_{\mathrm{ox}}\right)_{\mathrm{im}} \underset{k_{-1}}{\stackrel{k_{1}}{\rightleftharpoons}}(\mathrm{ES})_{\mathrm{im}} \stackrel{k_{2}}{\longrightarrow}\left(\mathrm{E}_{\mathrm{red}}\right)_{\mathrm{im}}+\mathrm{P} \\
\mathrm{M}_{\mathrm{ox}}+\left(\mathrm{E}_{\mathrm{red}}\right)_{\mathrm{im}} \underset{k_{-3}}{\stackrel{k_{3}}{\rightleftharpoons}}(\mathrm{EM})_{\mathrm{im}} \\
\quad \stackrel{k_{4}}{\longrightarrow}\left(\mathrm{E}_{\mathrm{ox}}\right)_{\mathrm{im}}+\mathrm{M}_{\mathrm{red}} \\
\mathrm{M}_{\mathrm{red}} \stackrel{-n e}{\longrightarrow} \mathrm{M}_{\mathrm{ox}}
\end{aligned}
$$

ここで, $\left(\mathrm{E}_{\mathrm{ox}}\right)_{1 \mathrm{~m}},\left(\mathrm{E}_{\mathrm{red}}\right)_{1 \mathrm{~m}},(\mathrm{ES})_{1 \mathrm{~m}}$ 㐨よび $(\mathrm{EM})_{\mathrm{im}}$ はとれぞれ吸着酵素の酸化型, 還元型, 酵素-基 質複合体, 和よび酵素ーメディエータ複合体を意 味する. $k_{1}, k_{-1}, k_{2}, k_{3}, k_{-3}, k_{4}$ はそれぞれの段 階の速度定数である.Sすなわら Glc は電極に吸 


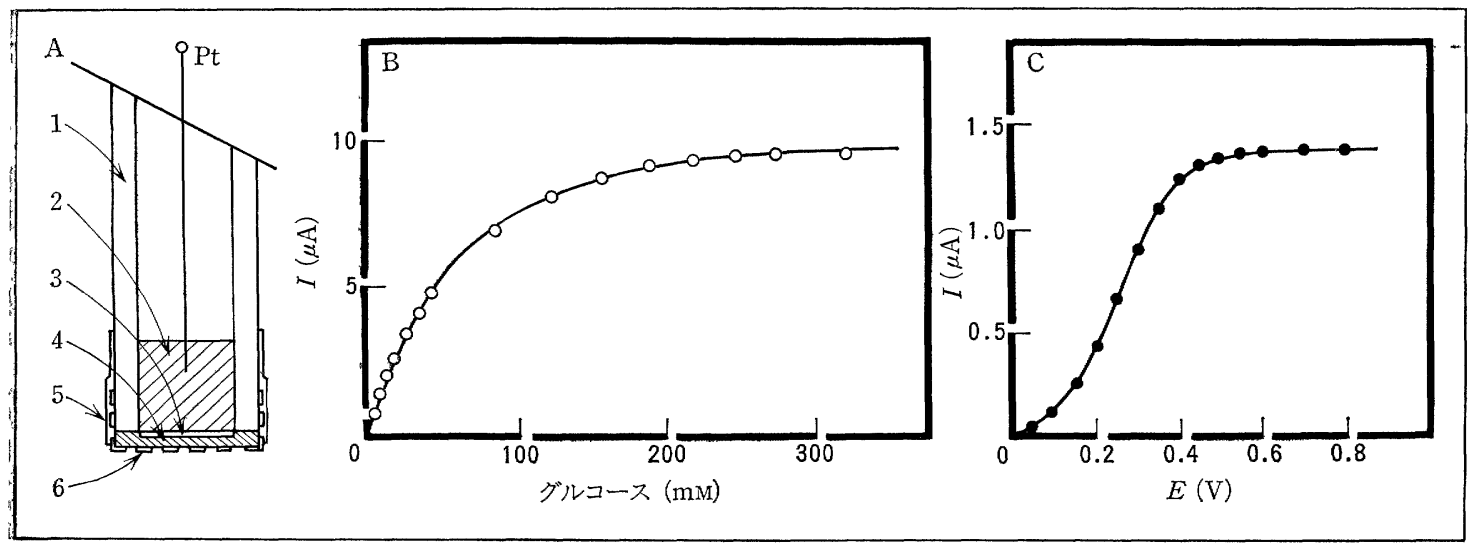

図 2 口酵素機能電極とその特性

$\mathrm{A}$ : 酵素機能電極の一例. $1:$ ガラス管, $2:$ メディエータ混合カーボンペースト, $3:$ 酵素層, $4:$ 半透膜, $5:$ 熱収縮テフロンテュ ーブ, 6:ナイロンネット

$\mathrm{B}$ : 膜被覆-GOD-カーボンペースト (BQ) 電極に和ける電流 $I$ の゙゙ルコース濃度依存性 $\left(\mathrm{pH} 7.0,25^{\circ} \mathrm{C}\right) . I$ は+0.5 V (飽和カ口 メル電極対) で測定

C : B と同じ電極に㘧けるIの電極電位依存性 (Glc : $125 \mathrm{mM}$ )

着固定された GOD によって酸化され，GODの 活性中心は還元型になる（2式）が， $\mathrm{M}_{\mathrm{ox}}$ に電子 を与えて元の酸化型に戻り， $\mathrm{M}_{\mathrm{ox}}$ が $\mathrm{M}_{\mathrm{red}}$ に還 元される (3式). $M_{\text {red }}$ の電極での酸化 (4 式) 炕より酸化電流が流れ， $\mathrm{M}_{\mathrm{ox}}$ が再生される. 定 常状態での酸化電流 $I$ は次式で与えられる.

$$
I=I_{\max } /\left[1+\left(K_{\mathrm{S}} /{ }^{\circ} c_{\mathrm{S}}\right)+\left(K_{\mathrm{M}} /{ }^{\circ} c_{\mathrm{M}}\right)\right]
$$
ここで,

$$
\begin{aligned}
& I_{\max }=n F A(\mathrm{E})_{\mathrm{im}} k_{2} k_{4} /\left[k_{2}+k_{4}\right] \\
& K_{\mathrm{S}}=\left[k_{4} /\left(k_{2}+k_{4}\right)\right]\left[\left(k_{-1}+k_{2}\right) / k_{1}\right] \\
& K_{\mathrm{M}}=\left[k_{2} /\left(k_{2}+k_{4}\right)\right]\left[\left(k_{-3}+k_{4}\right) / k_{3}\right]
\end{aligned}
$$

で与兄られる. 5 式は通常の酵素触媒反応の速度 式と同じ形をしている， $I_{\max }$ は酵素触媒反応に 扝ける最大速度に対応し， $K_{\mathrm{S}} ， K_{\mathrm{M}}$ はそれぞれ基 質，メディエータのミハエリス定数である. $n$, $F, A$ は電子数, ファラデー定数, 拈よび電極表 面積であり，(E) ${ }_{1 \mathrm{~m}}$ は単位表面積あたりの吸着酵 素量, ${ }^{\circ} c_{\mathrm{S}},{ }^{\circ} c_{\mathrm{M}}$ 璂質, メディエータの電極界面 での濃度である、反応は電極表面でしか起こらな いので，反応の進行とともに電極近傍では母液中 よりも基質濃度が低くなる，一般にはこの濃度変 化（濃度分極といら）を考慮しなければならない が，大抵の場合，溶液を通常のスターラーで適当 摫拌することによって濃度分極の影響を除くこ とができ，界面濃度を母液中濃度に等しいと置く
ことができる、したがって，I の基質濃度，メデ ィエータ濃度依存性の実験から $I_{\max }, K_{\mathrm{S}}, K_{\mathrm{M}}$ を 求めることができる. 酵素吸着電極の特性は，こ れらのパラメータの值で評価することができる。

センサーなどへの利用の見地からは，より多く の酵素を修飾固定した電極が望まれる，また， メ ディエータも電極自体に保持されていれば都合が よい，筆者らは，図 2-A に示すような膜被覆一酵 素固定化一メディエータ含有 カーボンペースト電 極を考案した.メディエータとして働く化合物を グラファイトとヌジョールから成るペースト中に 混合して電極とし，その上に酵素を透析膜のよう な半透性の膜で覆うことによって固定化してい る. 電極中の化合物は，その一部が電極と半透膜 の間の酵素層に溶出してメディエータとして機能 する. 図 2-B 飞は, 膜被覆-GOD 固定化-BQ 混 合カーボンペースト電極で得られた電流の Glc 濃度依存性を示す。 5 式から予想されるように, 電流は Glc 濃度とともに大きくなり, 飽和值に達 する．電流はまた，電極中に混合される $\mathrm{BQ}$ 量に も依存するが，重量比で数％程度混合すれば酵素 層中の $\mathrm{BQ}$ 濃度は $K_{\mathrm{M}}$ 值より十分大きくなり， 5 式は,

$$
I=I_{\max } /\left[1+\left(K_{\mathrm{S}} /{ }^{\circ} c_{\mathrm{S}}\right)\right]
$$

そ近似できる、ここで用いている電極では酵素の 


\begin{tabular}{|c|c|c|}
\hline 酵素 & 反応 & 補欠分子族 \\
\hline $\begin{array}{l}\text { 1. 酸化酵素 } \\
\text { 例. グルニースオキシダーゼ (EC 1.1.3.4) } \\
\text { 乳酸オキシダーゼ (EC 1.1.3.2) }\end{array}$ & $\mathrm{S}+\mathrm{O}_{2} \rightarrow \mathrm{P}+\mathrm{H}_{2} \mathrm{O}_{2}$ & フラビン, 銅, 非へム鉄硫黄 \\
\hline $\begin{array}{l}\text { 2. 酸化酵素 } \\
\text { 例. アスコルビン酸オキシダーゼ (EC 1.10.3.3) } \\
\text { ガラクトースオキシダーゼ (EC 1.1.3.9) } \\
\text { ラッカーゼ（EC 1.10.3.2) }\end{array}$ & $\mathrm{S}+1 /{ }_{2} \mathrm{O}_{2} \rightarrow \mathrm{P}+\mathrm{H}_{2} \mathrm{O}$ & へム, 銅 \\
\hline $\begin{array}{l}\text { 3. 脱水素酵素 } \\
\text { 例. フルルクトースデヒドロゲナーゼ (EC 1.1.99.11) } \\
\text { グルコースデヒドロゲナーゼ (EC 1.1.99.10) } \\
\text { グルコン酸デヒドロゲナーゼ (EC 1. 1.99.3) } \\
\text { ジアホラーゼ (EC 1.6.99.-) }\end{array}$ & $\mathrm{S}+\mathrm{M}_{\mathrm{ox}} \rightarrow \mathrm{P}+\mathrm{M}_{\mathrm{red}}$ & フラビン, ヘム, $\mathrm{PQQ}$ \\
\hline $\begin{array}{l}\text { 4. 脱水素酵素 } \\
\text { 例. アルルコールデヒドロゲナーゼ (EC 1.1.1.1) } \\
\text { 乳酸デヒドロゲナーゼ (EC 1.1.1.27) } \\
\text { グルコースデヒドロゲナーゼ (EC 1.1.1.118) }\end{array}$ & $\begin{array}{l}\mathrm{S}+\mathrm{NAD}^{+} \rightarrow \mathrm{P}+\mathrm{NADH} \\
\left(\mathrm{NADP}^{+}\right) \quad(\mathrm{NADPH})\end{array}$ & - \\
\hline
\end{tabular}

$\mathrm{PQQ}:$ ピロロキノリンキノソ, $\mathrm{M}_{\mathrm{ox}}$ : ジクロロフェノールインドフェノール (DCIP), ヘキサシアノ鉄(III)酸イオン

層はある厚みを持つので，この層中での基質の濃 度分極も考慮する必要があり，その効果はティー レモジュール

$$
\sigma^{2}=\left[k_{\text {cat }}(\mathrm{E}) l / K_{\mathrm{S}}\right] /\left[D_{\mathrm{S}} / l\right]
$$

の,值で評価できる.ここで $k_{\text {cat }}=k_{2} k_{4} /\left(k_{2}+k_{4}\right)$, (E) 酵素層中の酵素濃度, $l$ は酵素層の厚さで, (E) $l$ が 6 式の $(\mathrm{E})_{\mathrm{im}}$ に相当する． $D_{\mathrm{S}}$ は基質の この層中の拡散係数を意味する. $\sigma<5.0$ であれ ば，9式の表現形式がそのまま $5 \%$ の精度で使觉 る.ただし， $I_{\max }$ と $K_{\mathrm{S}}$ は見かけの值 $I_{\max }^{\prime}$ お よび $K_{\mathrm{S}}^{\prime}$ で置き換えられる。これらの見かけの 定数は濃度分極効果を含んで和り, それぞれの電 極に特有の值となる. $I_{\text {max }}^{\prime}, K_{\mathrm{s}}^{\prime}$ はとれぞれ $I_{\max }$, $K_{\mathrm{s}}$ より大さな值となる。この電極にはまた被覆 膜の層がある. この膜の 基質透過性が 小さい場 合，膜中で濃度勾配ができ， ${ }^{\circ} c_{\mathrm{S}}$ は溶液を攪拌し ても母液中の基質濃度 $c_{\mathrm{s}}$ と等しくはならない. 被覆膜の基質に対する透過性は次式,

$$
I=n F A p\left(c_{\mathrm{S}}-{ }^{\circ} c_{\mathrm{S}}\right)
$$

で表わすことができる，ここで， $p$ は被覆膜の基 質に対する透過係数である. 簡単のため基質の各 層間の分配係数は 1 と仮定した. 結局, この電極 の特性は $I_{\text {max }}^{\prime}, K_{\mathrm{S}}^{\prime}, p$ のつのパラメータで評 価できることになる。 $c_{\mathrm{S}}$ が $K_{\mathrm{S}}$ 值に近い場合で も，膜の透過性が低いと ${ }^{\circ} c_{\mathrm{S}}$ は $K_{\mathrm{S}}$ より十分小 さくなって，Iは $c_{\mathrm{S}}$ に比例する，こうして，電
極の基質に対する電流応答の直線領域は，ょり高 濃度側まで延びる，膜透過が律速となる場合，固 定化酵素の活性が少々低下しても電極の特性に影 響しない。また，膜の存在は試料液による電極の 污染を防ぐ効果も期待でき，センサーとしての機 能に寄与するところ大である.

次に，電極に加觉る電圧がどれくらい必要かを 考えてみよ5。電圧は, 溶液中に入れたもう の電極（銀/塩化銀電極や飽和カロメル 電極がよ く用いられる)との間に加えられる. 図2-Cに 示すように, この電極ではカロメル電極基準で $+0.4 \mathrm{~V}$ 以上の電位で一定の電流が得られるが, $0 \mathrm{~V}$ より負の電位では電流は流れない。負の電位 では $\mathrm{BQ}$ の電極反応 (4式) が起こらないからで ある，センサーとして使用するときは，一定の電 流が得られる $+0.4 \mathrm{~V}$ 以上の電圧を加える. 電流 の電位依存性は，主として用いるメディエータの 性質（酸化還元電位と電極反応の可逆性）で決ま る. $+0.4 \mathrm{~V}$ では, 試料中にビタミン $\mathrm{C}$ や尿酸が 共存するとこれらが直接電極で酸化されて測定の 妨害になるので，これらの酸化が起こらないよう な，もっと負の電位で一定電流を与えるようなメ ディエータがあれば好都合である，望ましいメデ ィエータの条件として, 低い酸化還元電位を持 ち，酵素とも電極とも速やかな電子授受反応を行 ない, 還元型が酸素に対して安定であることが挙 
げられる。

\section{2. どんな酵素が使えるか（何が測れるか（6,7)}

利用する酵素としては，基本的には酵素番号 1 に分類される酸化還元酵素が対象となる. 反応形 式の違いに基づいてこれらの酵素を分類したもの を表 1 に示した. 分類 $1 ， 2$ の酸化酵素の多くは キノン類やフェロセン類などを電子受容体とする ことができるが，中にはアスコルビン酸オキシダ 一ゼのように良好な電子受容体が見つかっていな いものもある. 3 の脱水素酵素では電子受容体之 してよく用いられる DCIP やへキサシアノ鉄 (III)酸イオンがメディエータとなる.40酵素で は, $\mathrm{NAD}^{+}$や $\mathrm{NADP}^{+}$自身をメディエータとす ることもできる、このなかで 3 に属する酵素は酸 素を電子受容体としないので, 溶存酸素の影響が なく大変都合がよい，いずれにしても，これらの 酵素のいずれかを用いれば，糖，アルコール，ア ミノ酸, ヌクレオシドやさらに亜硫酸イオンのよ うな無機物までも測定の対象とすることができる。 測定の基本原理は GOD の場合と同じである. 次に，特色あるいくつかの例を紹介しょう.

\section{フルクトースセンサー}

フルクトースデヒドロゲナーゼ $(\mathrm{FDH}, \mathrm{EC}$ 1. 1.99.11）を固定化した図 2-A の構成の電極を 用いる. FDH は表 1 の分類で 3 に属し, 酸素は 電子受容体とならない. 次の反応,

$$
\begin{aligned}
& \mathrm{D} \text { ーフルクトース }+\mathrm{M}_{\mathrm{ox}} \longrightarrow \\
& \text { 5ーケトーD-フルクトース }+\mathrm{M}_{\mathrm{red}}
\end{aligned}
$$

を触媒し, キノンやフェロセンなど種々の化合物 をメディェータとすることができる．ここでは $\mathrm{BQ}$ を用い, 厚さ $20 \mu \mathrm{m}$ の透析膜を被覆膜とし た。この系で，フルクトース濃度 $50 \mathrm{mM}$ まで良 好な検量線を得ることができ，0.1〜 $1 \mathrm{mM}$ の低 濃度領域では直線応答を示す. $\mathrm{pH} 3.5 \sim 6.5$ の範 囲で使用でき，電極の応答時間は 30 秒である. $\mathrm{FDH}$ の基質選択性が高いので，電極は他の糖類， すなわちグルコース，ガラクトース，スクロー ス, ラクトース，マルトース，キシロースやソル ビトールには応答を示さない，溶存酸素の影響も ない、しかし，アスコルビン酸は先に述べたよう
に電極で直接酸化されるため, 果物中のフルクト 一スの定量などに沶いては共存するアスコルビン 酸が正の誤差を与える、この影響は，たとえばア スコルビン酸オキシダーゼ (ASOD) を FAD と ともに電極に固定化することによって除くことが できる.アスコルビン酸は ASOD によって溶存 酸素で電極不活性なデヒドロアスコルビン酸に酸 化されてしまう. ASOD は BQ を電子受容体と しないので, FDH の反応と競合することはない. $0.2 \mathrm{mM}$ のフルクトース溶液に $0.1 \mathrm{mM}$ までア スコルビン酸が共存していてもその影響はみられ ない.オレンジ，グレープフルーツ，レモンなど の果物中のフルクトースを簡便に測定できる。リ ンゴのようにフルクトースをアスコルビン酸より 大過㮃に含む場合は ASOD なしの電極で十分測 定が可能である.

\section{アルドースセンサー}

オリゴ糖デヒドロゲナーゼ（ODH，東洋醸造; 現在旭化成）を用いる. この酵素も分類 3 に属 し，キノンなどを電子受容体とすることができ る.酸素は電子受容体とならない, 基質特異性は 低く，キシロースのよらなペントースからグルコ 一ス，ガラクトースのようなへキソース，さらに ラクトース, マルトース, マルトヘキサオースの ようなオリゴ糖も基質となる。ケトースであるフ ルクトースには応答しない. ODH を用い $\mathrm{BQ}$ メディエータとする電極は, これらのアルドース のすべてに電流応答を示す，酵素固定量と被覆膜 の厚さを変化させることによって，1 $1 \mu \mathrm{M}$ から 10 $\mathrm{mM}$ の広い濃度範囲で直線応答を示す電極が可能 であり，また図 3-A に示すように，単糖からマ ルトヘキサオースまで基質のサイズによって応答 感度が変化する電極も作製できる，ODH 電極は 選択性が低いので，混合溶液中の特定の糖のみを 検出することはでさない。しかし，1つの糖が他 の糖に比べて大過剩に含まれるような試料の場合 には問題はない。たとえば, ODH 電極は牛乳中 のラクトースを大変簡単に測ることができる.

$0.1 \mathrm{M}$ リン酸緩衝液 ( $\mathrm{pH} 7.0$ ) で牛乳を $1 / 10$ か ら 1/100 程度に希釈するだけで, 前処理なしにた だちに測定ができる，ODH 電極はまた，クロマ 


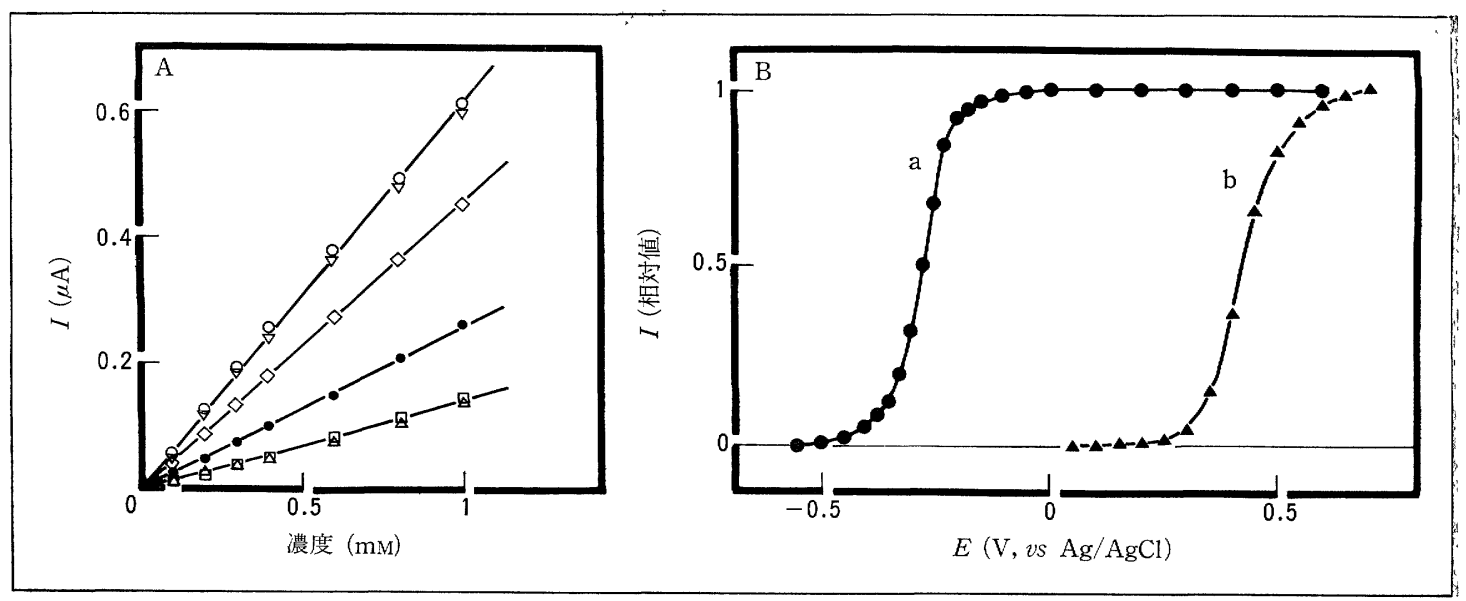

図 3 m各種糖類の検量線 (A) と NADH の酸化電流の電位依存性 (B)

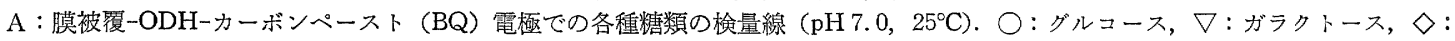
マルトース, : マ マルトリオース, $\square:$ マルトペンタオース, $\triangle:$ : マルトヘキサオース

$\mathrm{B}$ : 膜被䠗一ジアホラーゼーカーボンペースト (ビタミン $\mathrm{K}_{3}$ ) 電極 (a) 抒よび膜被覆ーカーボンペースト電極 (b)での NADH の酸 化電流の電位依存性

トグラフィーの還元糖類検出用電極としての利用 も考学られる. この電極の別の利用については後 で述べる.

分類 3 亿属する酵素を用いれば，まだまだいる いろなセンサーが可能である. グルコース，グル コン酸, メタノール, エタノール, グリセロール, ポリアミンなどに対するセンサーが作製できる. 分類 1 に属する酵素もよく用いられている. グル コース以外にグリコール酸, コリン，グルタミン 酸, ピルビン酸, キサンチン, サルコシン, 亜硫 酸に対するセンサーが報告されている。この場 合, 酸素も電子受容体として働くので, 溶存酸素 の影響に注意する必要がある，一例を次に紹介す る。

\section{ヌクレオシドセンサー}

Flavobacterium より 精製したヌクレオシドオ キシダーゼ (NOD) を用いる(8). この場合も $\mathrm{BQ}$ をメディエータとすることができ，図 2-A の型 の NOD 電極がヌクレオシドセンサーとなる. $\mathrm{pH}$ 6〜10 の緩衝液中でアデノシン, グアノシン, イノシン, ウリジン, チミジン, シチジンに応答 する，応答感度は前 3 者では注济同じであり, 後 3 者ではその $4 / 5$ 程度である. 2 30 $\mu \mathrm{M}$ の濃度 領域で直線応答を示し, その変動係数は $2 \%(n=$ 7) である.この誤差範囲内では溶存酸素の影響
はなく，少なくとも 2 か月は使用できる、 ヌクレ オチダーゼを一緒に用いればヌクレオチドの検出 もできる.

ところで, 同じヌクレオシドオキシダーゼ活性. を示す酵素でもPseudomonas maltophilia 由来 の NOD は BQ をメディェータとすることがで きない.メディニータは個別の酵素についてそれ ぞれ調べてみる必要があるが，この NOD には適 当なメディエータがない、ただ，この NOD は面 白い性質を持っている. すなわち，ラッカーゼ活 性も併せ持っており，しかもこのラッカーゼ活性 は NOD 本来の基質であるヌクレオシドが存在 するときにしか見られず，2つの反応には化学 量論的な関係がある. 反応の詳細はともかく, NOD は溶存酸素によってヌクレオシドを酸化す ると同時に，ヒドロキノンを $\mathrm{BQ}$ に酸化する.

$\mathrm{BQ}$ は電極でヒドロキノンに還元することができ るので，この還元電流を測ることによって，この NOD 電極もヌクレオシドセンサーとして用い ることができる.

\section{NADH センサー}

分類 4 にあげた $\mathrm{NAD}^{+}, \mathrm{NADP}^{+}$を補酵素とす る脱水素酵素の場合は, 補酵素自身が電極活性で あるので，これをメディエータにすることができ る.しかしながら，その電極での酸化はかなり正 
の電位で起こり，またこれらをカーボンペースト 中に練り达んだ場合，そのメディエータ特性は必 ずしもよいとはいえない，他の電極系に抢いても 事情は同じである。そこで，まず NADH 自身を 検出できる電極の検討が進められてきた．この電 極に各種の脱水素酵素を共固定すればバラエティ ーに富んだセンサーが期待でさる.

$\mathrm{NADH}$ センサーとして Bacillus stearothermophilus 由来のジアホラーゼ (EC 1.6.99. -, ユニチ カ）が適している.この酵素はいるいるなキノン 化合物やフラビンをメディエータとすることがで き, ビタミン $\mathrm{K}_{3}$ をメディエータとした場合の電 極では図 3-Ba に示すように - $0.2 \mathrm{~V}$ 付近ですで に一定の電流值に達する。これは， $\mathrm{NADH}$ を電 極で直接酸化した場合（図 3-Bb）よりも0.7 V も負の電位であるが，アスコルビン酸の影響を完 全に除くには，さらにもら少し低い電位である必 要がある、この電極の検量線は，溶存酸素を除く と 10\% ほど感度が上がる。これは，酵素反応で 生成した還元型ビタミン $\mathrm{K}_{3}$ が溶存酸素で一部自 動酸化することを示唆している.

\section{3.メディエータを高感度で測る; 加水分解酵素 の活性を測る}

酵素機能電極に括いて，メディエータは電極と 酵素の間にあって酸化還元を繰り返す。そこで見 方を変えて，基質大過㮃のもとでメディエータの 定量を行なえば，サイクリング増幅によって高 い感度の測定がでさる２つの酵素反応間での
目的物質のサイクリングによる高感度測定はよ く知られているが，電極上に固定化した酵素系で $\mathrm{NAD}^{+} / \mathrm{NADH}$ にこの方法を適用すれば，この補 酵素の高感度定量ができる. 先述のジアホラーゼ 電極にさらにグルコース-6-リン酸デヒドロゲナ ーゼを共固定しグルコースー6ーリン酸大過剩の もとで $\mathrm{NAD}^{+}$と $\mathrm{NADH}$ 間のサイクリングを行 なわせると，数 $\mathrm{nM}$ (絶対量で数ピコモル) まで 定量可能である. また, ドーパミンやノルエピネ フリンをラッカーゼ電極や GOD 電極のメディェ 一タとして可溶化状態で作用させると，これらの 高感度定量ができる ${ }^{(9,10)}$.

$$
\text { pーアミノフェノールは, ジアホラーゼや GOD }
$$
などの良好な電子受容体として働く、アルカリホ スファターゼなぞの多くの加水分解酵素の活性測 定には, $p$-ニトロフェニル誘導体が用いられ, 酵

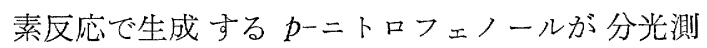
定される、ここで $p$ ーアミノフェニル誘導体を用

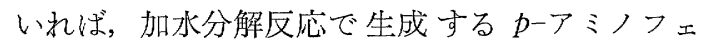
ノールをジアホラーゼや GOD を用いるバイオエ レクトロカタリシス反応によって高感度定量する ことができ, 加水分解酵素の高感度アッセイがで きる、実際に，ジアホラーゼを用いた場合， 0.5 $\mathrm{nM}$ の $p-ア ミ ノ フ ェ ノ ー ル の$ 検出ができ, $10^{-7}$ ユニット $\left(4 \times 10^{-19} \mathrm{~mol}\right)$ のアルカリホスファタ 一ゼ活性の測定が可能である ${ }^{(11)}$.

先に述ベたアルドースセンサーやヌクレオシド センサーもまた，アミラーゼやヌクレオチダーゼ の活性測定に用いることができる.アミラーゼ反

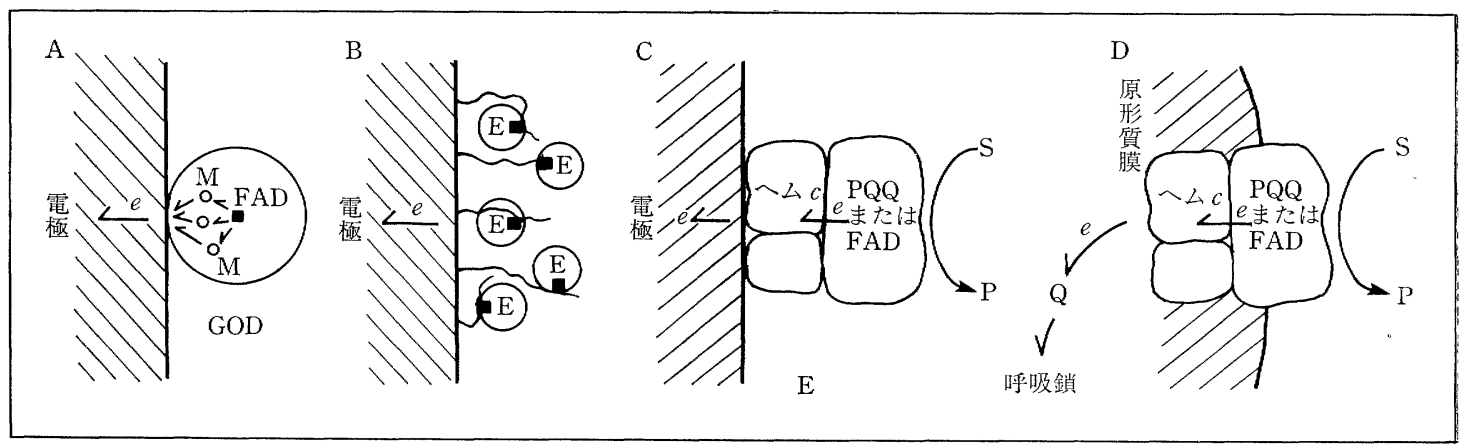

\section{図 4 酸化遥元酵素亡電極との電子移動}

$\mathrm{A}$ ：メディエータ $(\mathrm{M})$ による酵素の修飾， B : 酵素 $(\mathrm{E})$ と電極を電子の電線で結ぶ, $\mathrm{C}$ : 複合タンパク質からなる酵素の配向固 定, D : 細菌細胞膜のフラボヘムタンパク質, キノヘムタンパク質 
応の基質としてマルトペンタオースを用いると， 反応の進行とともにマルトースとマルトトリオー スができてくる.アルドースセンサーはこれら 3 種の糖に対する応答感度が異なる（図 3-A). 乙 たがって，電流応答の時間変化から，標準アミラ 一ゼ溶液での結果と比較することによって容易に ヒト血清中アミラーゼのアッセイがでさる.

\section{酵素-電極間電子移動の分子レベルでの研究 ${ }^{(12 ~ 18)}$}

酸化還元酵素の活性部位と電極との電子移動を 効率的に行なわせようとして, 様及な試みがなさ れている. バイオセンサーへの利用という立場か らも，電極の微小化ができるので大きな関心が持 たれている. 図 $4 \mathrm{~A} \sim \mathrm{C}$ に代表的な 3 つの例を示 す. 図4-A の例は, 酵素分子自身にメディエータ を埋め达んで電極と活性部位との間の電子のリレ 一としょらとするものである(14). GOD 分子を $2 \mathrm{M}$ 尿素中で部分変性させた後, GOD 分子中の 12１4個のリジン残基にフェロセンカルボン酸を 結合させた．このフェロセン修飾 GOD を溶液中 飞加光たところ, 期待どおりのバイオェレクトロ シス反応によって Glc を電極で酸化することが できた，ところが，この修飾酵素を電極表面に固 定化すると機能が極端に低下してしまった．固定 化されると，たまたま中継点が電極表面の汪うを 向いているごくわずかの分子だけしか働かないた めと考觉られている。

このような考えの下に，より効率の良い方法と して提案されたのが図 4-B である. 電極と一定 の距離を隔てて固定された酵素の活性部位へ電極 から橋をかけて電子の通路，すなわち電線としよ うとするものである。たと竞ば，4-ビニルピリジ ンと4-アミノスチレンを 20:1 の比で含むポリ マーを用い, ピリジンの 7 残基に 1 つの割合でオ スミウム錯体を結合させ，残りのピリジン残基は ポリマーに正電荷を持たせるために $N$-メチル化 した・オスミウムがメディエーションサイトであ り，正電荷によってポリマーの水溶性を上げ，酵 素の負電荷領域との親和性をもたせている．この ポリマーは電極に自ら吸着し，乙かも GOD 酵素 分子をとのマトリックス中にとり込んで固定する
ことができる、このマトリックス中に Glc は自由 に出入りでき, オスミウムは電極と GOD 活性部 位とのメディエータとして働くことが示された。 すなわち，このポリマーは分子電線として働く. 最近, この方法で直径 $7 \mu \mathrm{m}$ の GOD マイクロ電 極が作られている(14).

筆者らは，酢酸菌のような細菌の細胞膜結合性 の酵素に注目した. これらの酵素の多くは, 図 4D に示すように複数の酸化還元部位を持ってお り，膜表面で基質を酸化し，その還元当量を膜内 の電子伝達系に渡す。すなわち, 電子の入口と出 ロが異なる.この種の酵素を基質との反応部位が 溶液側に向くように電極表面に配向吸着させれ ば，図 4-C のように基質からの電子は酵素分子 内を電子の通路として電極に渡されるのではない かと期待したそそして，そのようなことが実際に 起こっていると思われる結果を得ている ${ }^{(16)}$. 先に 用いた FDH はこのタイプの膜酵素であり,メデ ィエータなしの $\mathrm{FDH}$ 電極がフルクトースセンサ ーとして十分働くことも見いだしている.

ミトコンドリア膜中の複合体を構成する酵素 であるコハク酸デヒドロゲナーゼをグラファイト 電極吸着させた場合にも，このような一方向へ の電子の流れが起こる.電子素子になぞらえて分 子ダイオードなどと呼ばれている(15).チラコイド

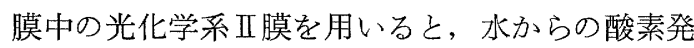
生に伴ら光電流が得ら机る(17)が，同じような呼び 方をすれば，これは分子光ダイオードとでも呼べ る.しかし，このような系の分子素子としての可 能性を論ずるのはまだまだ先の話であり, 現時点 ではもっと多くの実験例とその結果の定量的な解 析が必要であろう，X線結晶解析によって, 酸化 還元酵素や膜タンパク質についても, その高次構 造が決定されてきている，一方，電気化学におい ては, 電極表面の 分子修飾の 手法が 種々開発さ れ, また表面解析法の進歩も著しい, 酵素機能電 極の分子レベルでの研究の機は熟しているといえ る.

ところで, 分子レベルとは逆に, 細胞レベルで の酵素機能電極も可能であることを最後につけ加 えておきたい。たとえば酢酸菌を透析膜を用いて 
表面に保持した電極をエタノール溶液中に入れる と，ヘキサシアノ鉄(III)酸イオンの存在下でこの 電極はエタノールを酸化することができる(18). こ こでへキサシアノ鉄 (III)酸イオンは, 酢酸菌の細 胞膜酵素から電子を引き抜いて電極に渡すメディ エータの役割を果たしている、リアクターなどへ の利用を考える上でこのような電極も興味深い。

\section{文献}

1）鈴木周一編：“バイオセンサー”，講談社，1984.

2）千田 貢, 池田篤治：“高分子表面の機能と応用 (下)”，笺 義人編，化学同人, 1986, p. 201.

3) M. Senda \& T. Ikeda: "Bioinstrumentatıon", ed. by D. L. Wise, Butterworths, London, 1990, p. 189.

4) T. Ikeda, I. Katasho, M. Kamei \& M. Senda, Agric. Biol. Chem., 48, 1969 (1984).

5) T. Ikeda, K Miki \& M. Senda : Anal. Sci., 4, 133 (1988).

6) J.E.Frew \& H.A.O.Hill : Anal. Chem., 59, 933 A
(1987).

7）池田篤治 : 食品工業，34，31 (1991).

8）木下英明, 池田篤治, 古賀晋治, 清水 晶, 山田秀明 : 分 析化学, 41, 179 (1992).

9）和佐 保, 秋元建吾, 八尾俊男, 村尾澤夫：日本化学雑誌, 1984, 1398.

10) F Mizutani, S. Yabuki \& M. Asa1 : Biosens. Bıoelectron., 6, 305 (1991).

11) S. Yamaguch1, S. Ozawa, T.Ikeda \& M. Senda : Anal. Sci., 8, 87 (1992).

12）池田篤治: 食品工業, 35, 52 (1992).

13) J. E. Frew \& H. A. O. Hill : Eur. J. Biochem., 172, 261 (1988).

14) A. Heller: J. Phys. Chem., 96, 3579 (1992).

15) A. Sucheta, B. A. C. Ackrell, B. Cochran \& F. A. Armstrong: Nature, 356, 361 (1992).

16) T. Ikeda, S. Miyaoka, F. Matsushıta, D. Kobayashi \& M. Senda: Chem. Lett., 1992, 847.

17) T. Ikeda, M. Senda, T.Shıraishi, M. Takahashi \& K. Asada : Chem. Lett., 1989, 913.

18) T. Ikeda, K. Matsuyama, D. Kobayashi \& F. Matsushita: Biosci. Biotech. Biochem., 56, 1359 (1992).

\section{“The Protein Molecule-Conformation, Stability and Folding"}

蛋白質物理化学の権威である著者が，退官後 2 年にし て出版されたのがこの英書である・X線結晶解析により 原子レベルでの立体構造が解明されている蛋白質は数百 種類にも達し, また遺伝子工学による部位特異的変異を 起こさせた蛋白質に関する研究る日を追って増しつつあ る現況に执いて，この英書の上梓を見たのは正に時宜を 得たものとい光よう。まず序文において，1950 年代か らの蛋白質研究の歴史が述べられ，ついで各章の内容が 簡明に紹介されている. 章立ては,

第 1 章 アミノ酸側鎖の物理化学的性質

第 2 章 蛋白質の二次構造

第 3 章 蛋白質の三次構造

第 4 章 蛋白質分子の安定化因子

第 5 章 蛋白質の安定性

第 6 章 蛋白質分子の動的構造

第 7 章 蛋白質の立体構造形成

第 8 章 酵素触媒反応の一例, リゾチーム

となって和り，蛋白質研究の歴史飞沿って順序よく積及 上げられている.必要な数式もてい水い説明されて招 り，理解しやすい，登場する蛋白質は，いずれも立体構 造が判明しているものばかりであり, 研究の手法も実例
について具体的に述べられているので，研究者にとって もよい指針となるであろう．著者自身の研究室の業績も 少なからず引用されているが，特に筆者の印象に残った ものを2つ拾ってみよう。

$\kappa$ 型免疫グロブリンの $\mathrm{C}_{\mathrm{L}}$ フラグメントの変性状態か らの立体構造形成の時間経過を，C末端のCys につけ た螢光色素への Trp からのエネルギー移動を距離の尺 度として用い， $\operatorname{Trp}$ の螢光と $218 \mathrm{~nm}$ に打ける円二色 性とともに観測し、コンパクトな構造をもった中間体が 早い時間域にできることを見いだした（第 7 章）。また， リゾチームの 2 つの触媒残基 Asp 52 と Clu 35 の 4 つ の解離状態について, ミク口な解離定数を綿密に決定す るとともに，基質アナログ和よび螢光性の基質との結合 定数を決定し，さらに螢光性の基質については，ミカェ リス定数, モル活性などの $\mathrm{pH}$ 依存性を詳細江解析乙 て, Asp 52 と Glu 35 の触媒残基としての役割を確か なものとした (第 8 章)。このような綿密な実験之緻密 な解析はたやすくできるものではなく，著者の研究室な らではと思わせる。

全章を通じて淡々と書かれてはいるが，随所㵔著の “思想”と情熱を感じさせっれる名著である。

(廣海啓太郎)

(濱口浩三著, 学会出版センター, ) (1992年, 8300円，菊判，252頁，英文） 